DOI https://doi.org/10.30525/978-9934-26-146-6-30

\title{
ВИМОГИ ДО ЗАСТОСУВАННЯ \\ ОКРЕМИХ ЕЛЕМЕНТІВ ПСИХОЛОГІЧНИХ ТРЕНІНГІВ У ПРОЦЕСІ ВИКЛАДАННЯ ІНОЗЕМНОЇ МОВИ ЗА ПРОФЕСІЙНИМ СПРЯМУВАННЯМ У $3 В О$
}

\author{
Нестеренко Л. О. \\ кандидат наук з державного управління, доцент, \\ доиент кафедри англійської мови \\ факультету гуманітарних наук \\ Національний університет «Києво-Могилянська академія» \\ м. Київ, Украӥна
}

Професійна діяльність сучасних викладачів іноземної мови спрямована на пошук нових та дієвих способів мотивації студентів, особливих прийомів та засобів викладання великого обсягу матеріалу таким чином, щоб за обмежений часовий проміжок сформувати необхідні фахові знання основної професійної лексики та вміння ефективно користуватися ними в межах своєї майбутньої професійної діяльності.

Відтак, вирішальну роль в навчальному процесі, нині як ніколи раніше, посідають саме практичні заняття, під час яких студенти ознайомлюються 3 новими лексичними одиницями, опрацьовують автентичні тексти, вчаться використовувати здобуті знання на практиці, a розв'язання комунікативно-пізнавальних завдань здійснюється завдяки різноманітним сучасним засобам іншомовного спілкування: рольові ігри, навчальні ситуативні завдання, парні та групові форми роботи тощо $[1,3,6]$. Оскільки нові вимоги до викладання іноземної мови вимагають застосування нових підходів.

Саме тому все більше викладачів іноземної мови залучають до своєї професійної діяльності здобутки психологічної науки. Цей факт, поперше, пояснюється тим, що психологічні методи впливу вже довели свою ефективність у багатьох соціальних сферах, i це, на нашу думку, їх використання доцільним і у процесі викладання іноземної мови. По-друге ж, залучення психологічного інструментарію до процесу викладання іноземної мови за професійним спрямуванням у ЗВО дозволяє пришвидшити формування довіри між учасниками освітніх взаємодій та мінімізувати ймовірність виникнення непорозумінь у майбутньому $[3,7]$. Що у свою чергу, сприятиме суттєвому підвищенню загальної комунікативної компетентності студентів. 
Цей факт пояснюється унікальними можливостями використання окремих елементів психологічних тренінгів, що полягають у можливостях модифікації мотивації учасників шляхом демонстрації їх досягнень та недоліків; об' єктивацією поведінки та діяльності учасників тренінгів; досконалим оволодінням новими моделями комунікативної поведінки.

На підставі аналізу робочих програм з англійської мови [2] , що використовуються в Національному університеті «Києво-Могилянська академія» та безпосереднього досвіду отриманого у процесі використання окремих елементів психологічних тренінгів у ході викладання іноземної мови за професійним спрямуванням на Кафедрі англійської мови Факультету гуманітарних наук НаУКМА нами були визначені та сформульовані загальні вимоги до застосування психологічних тренінгів у процесі викладання англійської мови за професійним спрямуванням.

Так, на основі системного аналізу літературних джерел $[1,4,6,7]$ ми можемо сформулювати наступні вимоги щодо використання окремих елементів психологічних тренінгів у процесі викладання англійської мови за професійним спрямуванням:

- по-перше, встановити та детально охарактеризувати базовий комунікативний стандарт для програм з іноземної мови за професійним спрямуванням, що викладаються в ЗВО (під стандартом ми розуміємо мінімальний рівень комунікативних знань та вмінь студентів, оскільки ефективність ї професійної діяльності суттєво залежить від ефективності здійснення комунікації).

- по-друге, включити до навчальних програм та планів проведення занять $з$ використанням окремих елементів психологічних тренінгів. 3 детальними інструкціями щодо використанням та очікуваними результатами. Адже важливою особливістю використання психологічного інструментарію у процесі викладання іноземної мови (окрім першочергових завдань 3 розвитку комунікативної компетентності з іноземної мови, залучення психологічних тренінгів до процесу викладання іноземної мови за професійним спрямуванням), $\epsilon$ також: розвиток психологічних здібностей сприйняття студентами один одного; формування знань щодо особливостей процесу впливу на комунікацію суб'єктивного досвіду, стану та відношення учасників комунікації; створення передумов для адекватного ставлення до власних емоцій та емоційній поведінці співрозмовника в процесі комунікації; тощо.

- по-третє, визначити основні принципи використання окремих елементів психологічних тренінгів у процесі викладання іноземної мови 
за професійним спрямуванням в ЗВО. До таких принципів можна віднести принципи особистісного спілкування (в його основі лежить положення про злиття процесів спілкування і навчання, нерозривність навчально-пізнавальної І діяльності учнів та діяльності спілкування) та принцип колективної взаємодії (такий спосіб організації навчального процесу, де учні активно й інтенсивно спілкуються один 3 одним, обмінюючись навчальною інформацією, що сприяє розширенню знань, вдосконаленню навичок та вмінь кожного учня; між учасниками спілкування створюються оптимальні взаємодії i формуються характерні для колективу взаємовідносини, а умовою успіху кожного $є$ успіх інших членів колективу).

При цьому головною умовою використання окремих елементів психологічних тренінгів у процесі викладання іноземної мови за професійним спрямуванням в ЗВО має бути готовність орієнтуватися на іншу людину, визнавати цінність його особистості, брати до уваги інтереси партнера (гуманістичні цінності). Для цього на практичних заняттях 3 англійської мови можна використовувати групові дискусії, рольові ігри, зміст яких має відповідати змісту майбутньої професійної діяльності студентів.

Таким чином, дотримання основних вимог до використання окремих елементів психологічних тренінгів у процесі викладання іноземної мови за професійним спрямуванням в ЗВО забезпечить студентів не лише певним набором лексичних одиниць та граматичних конструкцій 3 певної теми, але й психологічними знаннями 3 основ комунікації, сформує практичні навички та вміння в сфері спілкування, скорегує наявні недоліки та сформує й розвине навички, необхідні для успішної комунікації, розвине здібності адекватного й повного пізнання себе та інших людей у ході подальшої професійної діяльності.

\section{Лiтература:}

1. Сзова С. А. Комунікативна компетенція. Наукові та технічні бібліотеки. 2008. № 4. С. 100-107.

2. Л.О.Нестеренко, Робоча програма навчальної дисципліни: Англійська мова (за професійним спрямуванням) для студентів ФСНСТ. Ухвалено на засіданні кафедри англійської мови. Протокол № 7 від 15 квітня 2019 року. Київ: НаУКМА, 2019.

3. Москаленко В. В. Соціальна психологія. Підручник. Видання 2-ге, виправлене та доповнене. - К. : Центр учбової літератури, 2008. 688 c.

4. Нестеренко Л. О. Особливості використання психологічних тренінгів у процесі викладання іноземної мови за професійним 
спрямуванням. Актуальні проблеми державного управління, педагогіки ma психологї̈: збірник наукових праць Херсонського національного технічного університету. Херсон: Грінь Д. С., 2014, Вип. 1 (10). C. $107-110$.

5. Про організацію вивчення гуманітарних дисциплін за вільним вибором студента. Наказ Міністерства Освіти і Науки України № 642 від 09.07.2009 p. - mon.gov.ua>images/newstmp/2010/25_08/831.doc. (дата звернення 12.07.2021).

6. Професійний стандарт на групу професій «Викладачі закладів вищої освіти», затверджений 23 березня 2023 року. URL: https://mon.gov.ua/storage/app/media/pto/standarty/2021/03/25/Standart\%20 na\%20hrupu\%20profesiy_Vykladachi\%20zakladiv\%20vyshchoyi\%20osvity _25.03.pdf (дата звернення 12.07.2021).

7. Румянцева И.М. Психотерапия на стыке наук: интегративный лингво-психологический тренинг в обучении иноязычной речи. Психологічні перспективи: Волин.нац.ун-т ім. Лесі Українки; Ін-т соц. та політ.психології АПН України. Луцьк, 2011ю - Вип.18 - С. 220-229.

DOI https://doi.org/10.30525/978-9934-26-146-6-31

\title{
АНАЛІЗ СКЛАДОВИХ МОДЕЛІ РОЗВИТКУ РУХОВИХ ЯКОСТЕЙ СТУДЕНТОК ЗАКЛАДІВ ВИЩОЇ ОСВІТИ В УМОВАХ ПРОФЕСІЙНОӦ ПІДГОТОВКИ НА АКМЕОЛОГІЧНИХ ЗАСАДАХ
}

\author{
Самохвалова I. Ю. \\ аспірант \\ Сумський державний педагогічний університет імені А. С. Макаренко \\ Харченко С. М. \\ кандидат педагогічних наук, \\ доиент кафедри фізичного виховання \\ Сумський національний аграрний університет \\ м. Суми, Украӥна
}

Стан здоров'я населення у сучасному світі $\epsilon$ показником рівня розвитку суспільства. Наслідки недостатньої рухової активності молодих жінок обумовлюють виникнення порушень в стані опорнорухового апарату, серцево-судинної, дихальної, ендокринної, травної 